\title{
THE KING AND I :
}

ANOTHER ORIENTALIA IN COMMERCIAL THEATRE?

\author{
Pawit Mahasarinand ${ }^{1}$
}

\begin{abstract}
One of the most popular American musicals, The King and I has always been, and probably will forever be, banned in Thailand. Its current Broadway production, ironically, petitioned to premiere in Thailand and, without hesitation, was immediately turned down by the Royal Thai Government. Instead, it was developed in Australia and moved to Broadway where it received critical as well as commercial success.
\end{abstract}

This paper, with the help of library and field research, briefly explores the history of the play's controversy and focuses on the theatrical and cultural aspects of the new production. It is supported by critical reviews of the production and in-depth interviews with its cast, the Thai Cultural Consultant, and Thai theatre practitioners who have seen the production. It leads to the conclusion that, as many American people know very little about Asians, "Asianness" can make much profit in the popular arts such as musical theatre.

\footnotetext{
1 Lecturer, Department of Dramatic Arts, Chulalongkorn University Bangkok Thailand
}

\section{The King and I: Another Orientalia ${ }^{2}$ in Commercial Theatre? ${ }^{3}$}

I recall the time when I was working for my master's degree in theatre at Northwestern University from 1994-6, and visited my directing professor Dominic Missimi in his office. Our conversation ended with a discussion of the musical play The King and I, especially on how Thai and true its story was, so one day I rented, and later bought, the videotape to watch. A few years later, on the first day I arrived in Ann Arbor, Michigan, I was taking a picture of the town with my camcorder and a local teenager said to his friend behind me, "Look at this Chinese guy, he probably hasn't seen such a big crowd." Slowly, I turned to them, and said

\footnotetext{
${ }^{2}$ The term first used by Edward Said in his famous book Orientalism, it is how the "masculine" West viewed and, for some, still views the "feminine" East as, for example, the exotic and uncivilized. In Intercultural Studies, as well as many other academic disciplines, the term "Oriental," when applied to Asians, is no longer politically correct.

${ }^{3}$ This paper was presented to the IFTR (International Federation for Theatre Research)'s $13^{\text {th }}$ World Congress "Theatre and Theatre Research: Exploring the Limits," at the University of Kent, Canterbury, United Kingdom. 6-12 July 1998.
} 
as politely as possible, "First of all, I live in Seattle. Secondly, I can understand every word you say. Lastly, I can speak English." A friend of mine who works at a Thai restaurant in Seattle often tells of American people who greatly enjoy Thai cuisine there but refer to the Thai waiterswaitresses as "Taiwanese." One of the best punch lines I always use as an introduction of myself to westerners is : "I'm from Thailand, and that's very far south of Taiwan." However, even Thai Duty Free shopkeepers usually speak English to me at Bangkok International Airport, Japanese flight attendants always speak Japanese to me on flights from the U.S. to Japan, and Hong Kong restaurant owners in London's Soho are surprised that I cannot speak Cantonese. So, what is actually going on?

In this paper, with the help of one year of library and field research, I will attempt to answer the question posed in the title: whether the 1996 Broadway production of The King and $I$ made as its selling point "Asianness," without a true understanding of the sensitivity of its cultures, or whether it is simply another Orientalia in commercial theatre.

One of the most popular American musicals, The King and I, from its highlyacclaimed original production in 1951, its world-renowned academy-award-winning film in 1956, to the present day, has always been, and probably will forever be, banned in Thailand, the land where it is set because of its offensive and fictitious nature. Margaret Landon's best-selling novel Anna and the King of Siam, on which the musical is based, was adapted from Anna Leonowens'personal chronicles The English Governess at the Siamese Court and The Romance of the
Harem. The musical play is, however, very lightly based on the true story. Anna Leonowens really did live in Siam in the reign of King Rama IV, yet her actual relationship with the king was much less significant, and intimate than she claimed in her chronicles, or depicted in Margaret Landon's best-selling novel and the subsequent musical play.

In the musical play; the product of secondary adaptation, King Rama IV, or King Mongkut, is presented as a socially inadequate person who has to be taught simple western manners, or as a Los Angeles Times article put it, "an Oriental bumpkin who had many wives but who required an English woman to teach him how to use a knife and fork." ${ }^{44}$ Although one may argue that the King Mongkut in the play is only a character, a fictionalized and dramatized man, and that Thai people should open their minds, take the play as a fantasy, not history, and simply enjoy it, the Thai public cannot but help having a strong reaction towards such a characterization, so the "aesthetic distance" of the play is more or less diminished. Throughout history, traditional Thai theatre and contemporary Thai films have never presented any member of royalty in such a negative, and faintly ridiculous, manner. 6

\footnotetext{
4 James Marnell, "Newsmakers," Los Angeles Times, 17 March 1985.

5 "Physical or psychological separation or detachment of the audience from the dramatic action, regarded as necessary to maintain the artistic illusion in most kinds of theatre." (Edwin Wilson, The Theater Experience, 415.) ${ }^{6}$ This code of censorship also applies to other countries' royal families. When the Hollywood parody film The Naked Gun was shown in Thailand, a scene in which Queen Elizabeth II was ridiculed was cut from its theatrical and
} 
Production teams have been aware of this sensitive issue since the beginning. A newspaper report which came out shortly after the opening of the original production reads:

Because Rodgers and Hammerstein were extremely anxious not to have anything in the musical version of the Anna and the King of Siam novel that might be offensive to Orientals, particularly the Siamese, Hammerstein sent someone to the Siamese Embassy in Washington to get an authentic reaction and, if possible, suggestions as to treatment. How- ever, their representative was given a brush, so the adapters went ahead on their own. As far as Rodgers and Hammerstein know, no Siamese officials have seen the show.?

The representative on his way to find the "Siamese" Embassy might have got lost somewhere along the Potomac river. There was no such place as the Siamese Embassy in 1951: by that year "Siam" had already been officially known as Thailand for 12 years. They should probably have looked for the Royal Thai Embassy instead. This is a small example of how little Americans knew, or cared to knew, about Asians.

Elsewhere, the controversy was also clear: the Australian government-controlled radio network banned the broadcast of any

VDO release in Thailand. In contrast, the film's sequel in which President George Bush was made fun of was shown in its entirety.

${ }^{7}$ Unknown source, 23 May 1951. music from The King and I during King Bhumibol and Queen Sirikit of Thailand's royal visit to Australia in $1962 .{ }^{8}$ In 1970 , a Scottish historian Ian Grimble said in a radio interview on $\mathrm{BBC}$ that Anna Leonowens, "I" in The King and I, was

A mischief-maker, a squalid little girl, one of those awful little English governesses, a sex-starved widow. She casts herself as an angel of light, come to redeem the Byronic monsters - a Jane Eyre leading Rochester back to light and life. At the same time she scolds Mongkut because he would not be led. ${ }^{9}$

Unfortunately, this has not been made widely known to audiences who have greatly enjoyed the musical play and many of whom even believe that the story is historically true.

In 1985, Yul Brynner, whose name had already been associated with the musical's and Broadway's history, invited Queen Sirikit of Thailand to view the performance on Broadway. Brynner, who had become famous because of his portrayal of King Mongkut in theatre and film, admitted to her, "We have done so many things about your country without really knowing it. But we do it with great love." In response, Queen Sirikit, through a spokeswoman, said that she did not take the Rodgers and Hammerstein's musical as an affront, but had only attended it

\footnotetext{
8 "No Music for the King," New York Herald Tribune, 24 August 1962.

9 Bernard Weinraub, "Briton Says Anna Was Awful in Siam," New York Times, 8 August 1970.
} 
because the show's star, Yul Brynner, invited her. "She thinks the show is fun. She and the King are open-minded and we all know that the court would never act like that," said her spokeswoman. ${ }^{10}$

Although the play and film have been banned for almost half a century, the original sources, Landon's novel as well as Leonowens' personal chronicles, have all been translated into Thai and widely read by Thai people. This suggests that theatre and film are generally considered more as popular arts, a public experience, and thus must face more censorship than literary arts, which are a personal experience. At the moment, a comparative study of the Leonowens' two chronicles, Landon's novel and the film is being conducted for a Master's thesis in Comparative Literature by a Chulalongkorn University graduate student. ${ }^{11}$

Amidst controversy, the current Broadway production petitioned to open in Thailand at the Kad Theatre in Chiang Mai, where local audiences had seen Australian productions of the American musicals South Pacific and Grease. It was immediately turned down by the Royal Thai Government. Even though more than 40 years has passed and Thailand has been westernized in many socio-cultural aspects, The King and $I$ is still deemed strongly offensive to the Chakri Dynasty, undoubtedly the most highly respected institution in Thai society. Instead, the musical production premiered in Australia

\footnotetext{
10 "King and Queen," Philadelphia Inquirer, 18 March 1985.

${ }^{11}$ Pornpaktra Chaiyaset, The Thai Image in Anna Leonowen's Works and Texts Influenced by Her Writings.
}

and moved to Broadway in 1996 where it enjoyed critical success, winning 4 Tony awards including Best Revival of a Musical; and popular success, drawing near-full-house audience and an extensive tour of the U.S.

It is noteworthy that the director Chistopher Renshaw, being aware of the play's fictitiousness, set forth the following production concept:

Respect for Thailand, its architecture, its customs, its religion, and its people became the order of the day for this new production of Rodgers and Hammerstein's classic. It was essential we attempted to capture as much authenticity of the real Siam in our sets and costumes as possible. $^{12}$

Although he expressed some cultural concerns, it is clear from this director's note that the production team was concerned more with spectacle. It reads as if he were trying to add authenticity to fiction, trying to recreate the visual images Anna Leonowens saw in Siam, a difficult and time-consuming theatrical task. However, it is clear that in the end dramaturgy and research were not in the picture: "Much of the design was inspired by photographs taken on that trip." 13 A local source who worked with the director in another production alleges "that trip" was not at all a research trip, but one made for pleasure during his staging of

\footnotetext{
${ }^{12}$ This was published in the booklet accompanying The King and $I$ 's "New Broadway Cast Recording" compact-disc. 13 Ibid.
} 
South Pacific at the Kad Theatre. Moreover, a photograph can suggest a thousand words, but another million details may be left out of the frame. While Renshaw claimed, "Much of our fabric, headdresses, and jewelry were made there," $" 14$ the same local source confirms the fact that most of them were actually bought, not made-to-order in Thailand. It should be noted here that the production received Tony awards for Best Costume and Best Set Design.

As for casting, or how the historical characters are represented, Renshaw guaranteed that "apart from Mrs. Anna and the script's three other Caucasians, the cast would be Asian." 15 From my viewing of his production and my interviews with two cast members, ${ }^{16}$ Randall Duk Kim, and Doan MacKenzie, I have found that his cast mostly consists of AsianAmerican, not "Asian," actors and actresses. Some of these actors and actresses do not speak any Asian languages but are fluent in English, and most of them have never been to Asia, let alone Thailand. The director, as well as many of his audience, may not quite know the differences between Asians and AsianAmericans.

Kim, one of the most prominent AsianAmerican actors who is featured in the recently-published Shakepearean-Studies book Modern Hamlets, plays the Kralahome, the musical's most dominant part for Asians. He commented on the

${ }^{14}$ Ibid.

15 Ibid.

${ }^{16}$ This interview was conducted at the Neil Simon Theater on Broadway before the play's matinee performance on 17 May 1997.
"Asian" cast, "Whether the actor is Asian or not, it's the kind of actor who does not care to find out the truth of what's in the story he's telling. It's a job. You operate on a superficial understanding of things." Mackenzie, who was born in Bangkok to a Thai mother and an American father, grew up in St.Louis and was cast as a chorus dancer for his "Asian look," said, "Most of the cast are Asian-Americans. By saying that I mean they're not in touch with the culture they're from. They grew up in a society that spoonfed them Asianness. I'm not exempted from that." For this production, added Kim, "Any Asians will do." Like another megahit musical Miss Saigon, The King and $I$ is simply a good job opportunity for AsianAmerican actors/actresses in the politically-correct casting scheme.

Renshaw's other innovation, putting some of the spoken text into Thai, instead of the "musical Siamese" tone used in the original production, sounds like a good idea at first; however, the lines are actually delivered by the non-native Thai speakers with the assistance of Deborah Hecht, an American dialect coach who studied from the book. To me, Anna's only Thai line in the musical 'Chan Ruk Khun,' or 'I love you,' delivered by Donna Murphy, who portrays Anna, sounds more authentic than those delivered by 'Asian' actors and actresses. MacKenzie, who can speak Thai very well, said of the American dialect coach:

She tried to make up these simplified rules, and they ended up sounding like Hindus, and God knows what else. When you're Asian, you have a very sensitive ear to other Asian cultures-you 
can tell if someone is Korean or Japanese. But when you're American, you tend not to. Or when you're Western, you don't have that good an ear. So any Asian accent is Asian. Therefore, those Asian people in the show have Asian accents.

MacKenzie was later appointed the Thai Accent Consultant for the touring production. I have seen the production and MacKenzie has done a fine job-all Thai lines were delivered more carefully and thus sounded less foreign to my Thai ears. It should also be noted that in the touring production a young American-born Thai actor, Andrew Guyvijitr, played the portrayed a significant supporting role of Prince Chulalongkorn, who succeeded to the throne after King Mongkut.

Kim was not at all happy with the production. At one point he even wanted to quit. He said "After I had accepted it, my concern was that I wasn't mounting another minstrel show. I was assured that the research had been done. It was only after the fact and when things began to evolve that I realized this had been lip service." MacKenzie concluded his interview: "Because the majority of our cast is not aware of their Asianness and they're so American, they come to accept that this is how the majority of American society views Asians; therefore, I'm giving them that."

Klailip Boonrai, another Thai actor who plays one of the "Siamese Children" in the production, is an eight-year-old Americanborn Thai who was raised by a Thai family in New York. Having performed in Miss Saigon and Madame Butterfly on the Great White Way, he is known as the
"Thai Kid." At the interview, ${ }^{17}$ he was proud of his only speaking line "Siam is the biggest country in the world," but did not fail to admit that it was totally wrong. His Thai parents are concerned with the sensitive issues in the musical: Chanin, his father, said, "The first time I saw him in costume, I was shocked. This is not the kind of costume a Thai person casually wear. So we asked him to pay respect to the costume, because it's a replica of what our kings and princes wore." He added, "I would mind most if the show destroys the image of our country, if it goes over the limits. When we watched the run-through, I felt it was all right." The show did not put its only Thai actor into the spotlight of advertising. Thai people in New York are not so excited about Broadway and not many people know Klailip was in the Broadway show. He went to Thailand last year and appeared as the Thai Broadway actor on a prime-time TV talk show but no "sensitive issues," were raised, to avoid any controversy, and that is the end of his story. The majority of Thai people have never even seen any Broadway productions and do not consider Broadway actors/actresses as "celebrities."

Before opening on Broadway in late 1996, after the production had enjoyed a long run in Australia, Ritirong Jiwakanon ${ }^{18}$ was hired as the production's Thai Cultural

\footnotetext{
${ }^{17}$ This interview was conducted in the presence of Chanin and Pensuda Boonrai, Klailip's parents, at the Siam Inn Restaurant before the evening performance on 17 May 1997.

${ }^{18} \mathrm{~A}$ Thai theatre designer graduated with MFA in Design from Yale, he is currently a lecturer in Costume Design and Classical Thai Theatre at Department of Dramatic Arts, Chulalongkorn University.
} 
Assistant. He described his job in an interview: ${ }^{19}$

The job I did was to advise actors and actresses on how to speak Thai and speak English with the Thai accent. We all knew that it was impossible to get it all right so we got just the feeling of the language and understood it. Everyone took it very seriously especially the King (Lou Diamond Phillips). I also helped them with Thai customs. For this, I needed to understand whether the director intended to do it or if it was part of the choreography. Sometimes I helped them with blocking that involved Thai customs; for instance, in the scene when Tuptim is caught having an affair and brought into the palace, I told the director how the two soldiers should behave in the King's presence while holding Tuptim. We needed to understand the condition of the musical which requires a rhythm of excitement which is opposite to Thai manners; therefore, we had to adjust the Thai manners to fit the music. The actors were cast for their singing ability, no matter what nationality they were. It is a musical and the music is the most important.

19 This interview was via email on 8 June 1997. This is his answer to my questions: "How much do you were involved in the creation of the authenticity in the production? How much advice did you give? How much did they take?
I agree with Ritirong to a certain extent: Thai manners, in their theatricalization, can be adapted to a degree where they still maintain, in the director's words quoted before, "respect for Thailand,...its customs, its religion,..." One crucial question for any director working in intercultural theatre, probably not for those in commercial theatre, is how much culture needs to be studied and how much can it be adapted.

Ritirong believes that the production is an interpretation, not a documentary, of Thai culture: The King and I is a musical play, not history. "I never tried to make it as realistic as I could. I think it would be nonsense to do so because, no matter what I did, it would not be real anyway. It was a great example of how people from one culture look at another."Although he made some strong comments on the design: "They (the designers) could not understand it all, especially the Thai costumes which are deeply involved with the complicated culture and social status. Therefore, many costumes were on the wrong characters and some looked too costumey," Ritirong was satisfied with the overall production and concluded, "This production of The King and $I$ still maintains the full meaning of Rodgers and Hammerstein's musical from a new point of view and has been triumphantly received by the audience."

Broadway critics appreciated the new "authentic" design and yet had a mixed reaction to the production. Nevertheless, it won the Tony award for Best Revival of A Musical. In contrast, the production was panned by a Thai theatre critic Kijja Buranon, who wrote one of the two critical reviews on the production published in Thailand: 
In the first scene, many women are hanging on posts high up in the air. I don't understand why Thai people have to be hanging like monkeys. Then, four monks make their rounds for food offerings under these women's feet. Some of them even spread their legs above the monks. These are the details any Western viewer would not notice, but Thai audiences would be shocked by the fact that inaccuracy starts as early as the play's first moment...The most offensive and ugliest of all scenes is when Anna is alone on the stage and sings the number Shall I Tell You that I Think of You? She is satirizing the king in front of the throne and I was shocked. My American friend had to stop me from shaking my head. They don't understand it the way we do. The fake throne is already offensive...It is pathetic to see their research fall so short with regard to the set and costume design... The production claims to have they sought assistance from Thai people via internet and finally a Thai waiter in Boston ${ }^{20}$ responded. I am not looking down on up waiters, but I do wonder why the big names in the theatre business, the seven producers from Australia and the U.S. could find no better person. ${ }^{21}$

${ }^{20}$ This is in fact Ritirong Jiwakanon, who, even when off work as Design Consultant for productions on Broadway has never worked at any Thai restaurant.

${ }^{21}$ Kijja Buranon, "The Thai Experience with The King and I," Di-Chan, 31 July 1996, 8688 (translated by Pawit Mahasarinand).
$\mathrm{He}$ concluded his critique: "It is a fun show for Westerners and non-Thais. This production should have paid more respect to our country and our king...I accept it as my karma to have had to sit through this production, ${ }^{22}$ and then listed the names of the seven producing companies as if to tell his Thai readers whom to blame.

Likewise, yet in a much milder tone, an excerpt from my short critique of the play published in a Thai newspaper reads:

The way everybody bows to the King is the same as the way they pay respect to the image of Lord Buddha: this is obviously an example of their lack of research. It would be interesting to see what Thai actors/actresses would do in this production with such interpretation and staging if they were cast. $^{23}$

My problem here, speaking from a Thai theatre director/critic's perspective, is not whether this production is historically and culturally accurate, but rather whether the director's ideal concept fails fully to be realised in the actual production.

Pichet Klincheun, a famous Thai classical dancer, in an interview, ${ }^{24}$ commented on the widely-known, critically-acclaimed, and "Thai-inspired" Jerome Robbins'

22 Ibid., 90.

23 Pawit Mahasarinand, "Another Side of Broadway," Krungthep Thurakij (Jud Prakai Section), 2 July 1997, 2 (translated by Pawit Mahasarinand).

${ }^{24}$ This interview was conducted, in Thai and later translated by Pawit Mahasarinand, via telephone on 22 May 1997, three days after his viewing of the production. 
choreography of the play-within-the-play scene "The Small House of Uncle Thomas:"

They got only the outside. The meaning of all the movements are unclear to me. I don't know what they want. They know in which direction they should point their arms and legs but there is no connection from one movement to another. It lacks Asianness; slowness. It is probably because of the music, but I believe the choreography could break away from the rhythm of the music if they really knew classical Thai dance movements. Some of the techniques are partly influenced by traditional Thai theatre, particularly the masked dance khon; for example, the part when Tuptim narrates the story The Small House of Uncle Thomas, and the chorus sings along and the dancers dance.

While he detested the production in general, Pichet noted that a Western audience would enjoy the show because, in his words, "The script makes Anna looks so smart. Western audiences love the fact that Anna helped modernise our country, making our country civilized. They're like Anna, so they're smart." Historically speaking, however, Anna Leonowens stayed in Thailand, or "Siam" as you will, for only five years. She rarely met King Mongkut in person and played very little part in the modernization, or westernization, of the country, much less than her claim in the diaries.

Patravadi Mejudhon, a veteran Thai actress-dancer-director-producer, was cast as a dancer in the 1981 American touring production of The King and I. In an interview, ${ }^{25}$ she recalled her Orientalia experience: "They (other actors/actresses) looked at my face. They tried to come up with a make-up style that would make them look like me. They even used Scotch tape. It didn't work. They'll always be Caucasians." Patravadi commented on the musical play The King and I, "They're not representing Thai culture. They are westerners, so they do it in a western way. I think they could do an authentic Thai production, but it's not their job. We have to do it authentically, because it's our job." Recently, she successfully adapted Jerome Robbins' choreography of The Small House of Uncle Thomas, the playwithin-a-play, a traditional Thai theatre showcase scene in which the major characters are watching the performance, and can be omitted, Patravadi said:

We invited some traditional dancers to try this out. However, we didn't try the Khon (masked dance), as Khon is more elite, and they probably wouldn't want to experiment in such a way. For all other parts, we adapted Jerome Robbins' choreography to fit into the Thai classical dance movements. We used their backing tracks, keeping all the characters' names. It was performed once for a mostly western audience at a private party. I think it was beautiful. Originally, I didn't like Jerome Robbins'choreography at

\footnotetext{
${ }^{25}$ This interview was conducted, in Thai and translated by Pawit Mahasarinand, at the lobby of Grand Hyatt Hotel, New York City on 17 May 1997.
} 
all. Now that I've experimented with it, I think it is a beautiful piece. I think it can be adapted to be more Thai. The traditional Thai dancers were also happy with it. They didn't think it was against convention. We let them do it the way they usually do.

This is an example of how a certain part of the controversial play can be artistically brought back to its cultural roots. However, it is the production's most highlytheatricalized part containing no offensive elements, and the show was not in public, but presented only once at her private party. Still, it may be the beginning of a new interpretation.

Speaking of the ban after viewing the current production, Patravadi commented, "The show is banned to protect the untouchable King. It's good that we ban it, because the monarchy is the only institution we now have. People don't mind the ban: they can fly to New York to see the show. We're not so serious about this story." The fact is many fewer than $1 \%$ of Thai people have seen the production: theatre is no longer a mainstream cultural activity for Thai people, especially when they are suffering from the so-called TomYum-Kung disease.

The conclusion of a review of The King and $I$ by an American theatre scholar Eileen Blumenthal reads: "And, let's be honest, a Rwandan equivalent of The King and $I$ would probably be taboo in the current political climate. But of course we should not relegate this body of theatre to oblivion Since in its own way it is authentic documentary: it is a record and reminder of who we've been." ${ }^{26}$ An American scholar even admits that The King and $I$ is obviously another Orientalia in commercial theatre. The production's claim to authenticity is, therefore, a new selling-point, some kind of marketing strategy, carefully crafted by theatre producers in a politically-correct era. For those who are offended by the play, it might not be a bad idea at all for the production outlook to remain nonauthentic so that any audience, with some knowledge about Thailand, can never believe Anna's fantasy ever to be true. Then, my question here is not whether The King and $I$ is offensive and should be banned in Thailand, but how many more Orientalia theater productions an American audience would spend more than $\$ 60$ a ticket to see.

In conclusion, we choose to know what we want to know and many popular arts tend to confirm this. The King and I, both in its form and content, has fed its audience with what they already believe, and, as a result, has failed to challenge their minds. I wonder how many of The King and I audiences would know that Thai people are still proud of the fact that Thailand is the only country in South and Southeast Asia which has never been colonized by a "civilized" western country owing to the tireless efforts of King Mongkut and King Chulalongkorn in the country's modernization; and how many of them have seen Thai traditional theatre performed by Thai dancers. Thailand has been a democratic country politically led by a prime minister for 66 years now and still "The King" spiritually leads all Thai people's hearts.

${ }^{26}$ Eileen Blumenthal, "How Thai Is It?,"
American Theatre, July-August 1996, 7. 
The New York Times even acclaimed King Bhumibhol "The People's King." In 1995, a Hollywood film The Usual Suspects featured a scene in which a Los Angeles police detective, who had failed to understand his European suspect, tells his partner, "He sounded like a Thai whore." The movie later won the academy award for Best Original Screenplay. Prostitution in Thailand is also the subject matter of Anthony Minghella's ${ }^{27}$ West-End play Made In Bangkok, which won the Best Play award from Evening Standard. Now, I look forward to watching a new film version of the musical play "Anna and the King of Siam," starring Jodie Foster, as Anna, and Chow Yen Fat, as King Mongkut; as well as the controversy it will cause when it is released.

After all this, may I conclude by quoting, ironically, Christopher Renshaw, The King and I's Tony-Award-winning director, "Thailand is a country of contrasts." I cannot agree more with him. When it comes to popular arts, such as theatre and film, it is a matter of which side of the coin an artist chooses to present to the public, or whether one would take a commercial risk and present both sides. Lastly, I, a Thai, not Siamese, man-an Asian, not Oriental, man-would kindly ask you, with my fake British accent, "Shall we dance?"28

27 One of the most famous contemporary British playwrights, he is now better known for his adaptation and direction of the multiaward-winning film The English Patient.

${ }_{28}$ One of the play's most famous and memorable musical number performed when Anna introduced polka dance to King Mongkut, it is also the title of a criticallyacclaimed Japanese movie recently released.

\section{References}

Boonrai, Klailip. Interview by Author. Tape Recording. New York, NY (17 May 1997).

Blumenthal, Eileen. (July-August 1996). "How Thai Is It?." American Theatre .

Buranon, Kijja. (31 July 1996). "The Thai Experience with The King and I." DiChan .

Jiwakanon, Ritirong. (8June1997). Interview by Author. Email. Seattle, WA.

Kim, Randall Duk; and MacKenzie, Doan. (17 May 1997).Interview by Author. Tape Recording. New York, NY

"King and Queen." (18 March1985). Philadelphia Inquirer .

Klincheun, Pichet. (22 May 1997). Interview by Author. Telephone and Tape Recording. Seattle, WA

Landon, Margaret.1945. Anna and the King of Siam. New York: Garden City Publishing, 1945.

Leonowens, Anna Harriette.1870. The English Governess at the Siamese Court. Boston: Fields and Osgood, . 1991 The Romance of the

Harem. Charlottesville: University Press of Virginia. 1992. Siamese Harem Life.

London: A. Barker, 1952.

Mahasarinand, Pawit. (2 July 1997). "Another Side of Broadway." Krungthep Thurakij.

Marnell, James. (17 March 1985). "Newsmakers." Los Angeles Times

Mejudhon, Patravadi. (17 May 1997). Interview by Author. Tape Recording. New York, NY.

"No Music for the King." New York Herald Tribune. (24 August 1962).

Weinraub, Bernard. (8 August 1970). "Briton Says Anna Was Awful in Siam." The New York Times.

Wilson, Edwin.1994. The Theater Experience. New York: McGraw-Hill. 